\title{
MENINGKATKAN PRESTASI BELAJAR FISIKA SISWA MELALUI PENGGUNAAN MODEL PEMBELAJARAN PROBLEM BASED INTRODUCTUON DI KELAS X/MIA-4 SMAN 1 SUMENEP TAHUN PELAJARAN 2013/2014
}

\author{
Zainal Hasan \\ Guru Fisika SMAN 1 Sumenep
}

\begin{abstract}
ABSTRAK
Tujuan dari penelitian ini adalah untuk meningkatkan prestasi belajar fisika siswa di kelas X-MIA 4 SMA Negeri 1 Sumenep tahun pelajaran 2013/2014. Pendekatan metoda penelitian ini adalah deskreptif kualitatif menggunakan analisis program SPSS versi 11.05 for Windows, sedangkan jenis penelitian ini adalah penelitian tindakan kelas(Collaborative Classroom Action Reseach) dengan populasi/sampelnya adalah siswa kelas X-MIA 4 SMA Negeri 1 Sumenep tahun ajaran 2013/2014, Pengambilan sample dalam penelitian ini menggunakan teknik Cluster Random Sampling terdiri dari 37 siswa mewakili kelas yang tidak diteliti. Data sample diperoleh dengan menggunakan teknik observasi, angket Interviw, documenter dan hasil test. Kesimpulan yang diperoleh adalah pada tahun pelajaran 2013/2014 penggunaan model pembelajaran problem based introductuon dapat meningkatkan prestasi belajar fisika siswa di kelas X-MIA 4 SMA Negeri 1 Sumenep. Hasil penelitian ini diharapkan dapat digunakan sebagai referensi sekaligus sebagai rekomendasi kepada pihak terkait guna peningkatan mutu pendidikan di sekolah masing-masing.
\end{abstract}

Kata Kunci : Model Pembelajaran Problem Based Introductuon (PBI), Prestasi Belajar.

\section{PENDAHULUAN}

Fisika sering disebut base of science (ilmu pengetahuan dasar) sesungguhnya tidak terlalu sulit untuk dipahami dan dikuasai, bahkan ada yang menyatakan bahwa fisika itu mudah (Yohanes S., 2000). Pada pembelajaran fisika materinya sangat luas, kompetensi guru sangat berpengaruh terhadap hasil belajar siswa (Depdikbud,1994). Metode problem solving, eksperimen dan observasi untuk memahami gejala alam dan lain sebagainya, merupakan salah satu di antara metode yang harus digunakan dalam pembelajaran problem based introduction. Konsep fisika pada umumnya merupakan konsep berjenjang dari konsep sederhana ke konsep yang lebih komplek.

Fisika merupakan bagian ilmu pengetahuan alam, pada jenjang pendidikan dasar dan menengah di Indonesia, perkembangannya banyak mengalami berbagai kendala, diantaranya menyangkut masalah $\begin{array}{r}\text { prasyarat } \\ \text { penunjangnya }\end{array}$ yaitu
penguasaan matematika dan penerapan proses belajar mengajar serta hasil belajar itu sendiri (Depdikbud,1999) Selama ini terdapat anggapan dan kesan dari siswa bahwa fisika itu sulit dan rumit sehingga banyak siswa yang enggan mempelajarinya. Lembaga pendidikan formal di SMA Negeri 1 Sumenep merupakan sebuah sekolah yang dianggap favorit oleh masyarakat sekitarnya, kemudian menurut data keadaan muridnya mempunyai IQ diatas rerata (Dewi Sundari, 2000:4 dalam Efektivitas Kurikulum, 1994). Namun kenyataan dilapangan nilai prestasi belajar mata pelajaran fisika siswa masih dibawah standar ketuntasan belajar minimum atau belum menunjukkan peningkatan yang signifikan. Hal ini disebabkan karena kompetensi guru yang kurang cakap, kurang relevan dalam memilih penggunaan multi metoda, strategi, 
pendekatan model pembelajaran dalam melaksanakan kegiatan pembelajaran.

Pembaharuan sistem kurikulum 1994 menjadi kurikulum 2004 yang lebih dikenal dengan Kurikulum Berbasis Kompetensi (KBK), kurikulum 2006 dikenal dengan KTSP silabus pembelajarannya disusun berdasakan kearifan sekolah masing-masing sampai pada kurikulum 2013 yang menekankan pembelajaran dengan metoda saintifik, pada dasarnya merupakan salah satu upaya untuk meningkatkan mutu pendidikan khususnya peningkatan hasil atau prestasi belajar siswa. Strategi pembelajaran dalam kurikulum yang digunakan, mengalami penggeseran dari yang mengutamakan pemberian informasi (pemberian konsep) menuju ke suatu strategi pembelajaran yang mengutamakan keterampilan berfikir untuk memperoleh sesuatu tentang konsep. Penggeseran dari pemilihan strategi pembelajaran tersebut secara otomatis peran guru dikelas menjadi berubah yaitu peran sebagai penyampai materi pelajaran (transformator) menjadi peran sebagai motivator dan fasilitator atau dari teacher centered menjadi student centured (Kurikulum 2004, Depdiknas ). Penggeseran peran guru terhadap siswa dalam proses kegiatan pembelajaran, semuanya tidak terlepas dari tanggung jawab sosok seorang guru yang harus memperhatikan aspek pendidikan diantaranya adalah meningkatkan perkembangan aspek kepribadian siswa secara utuh dan menyeluruh.

$$
\text { Langkah kongkrit untuk }
$$

memecahkan masalah yang berkaitan dengan prestasi belajar fisika siswa di kelas X/MIA-4 SMA Negeri 1 Sumenep, secara maximal diantaranya adalah menghimbau kepada para guru fisika dalam memilih, menggunakan berbagai strategi, pendekatan dan metode, model pembelajaran yang aktif, kreatif, efektif dan menyenangkan (Pakem). Salah satu dari model pembelajaran yang telah diramu, dikemas dan dirancang kemudian disesuaikan dengan karakteristik pembelajaran fisika yang menyenangkan (enjoy full learning) adalah pembelajaran yang berdasarkan masalah (Nurhadi, 2003:55).

Berdasarkan latar belakang masalah tersebut diatas, maka penelitian ini mempunyai tujuan sebagai berikut :

1. Meningkatkan prestasi belajar siswa di kelas X/MIA-4 SMA Negeri 1 Sumenep tahun ajaran 2013/2014

2. Untuk memperbaiki pembelajaran fisika di kelas X/MIA-4 SMA Negeri 1 tahun ajaran 2013/2014

3. Meningkatkan kreatifitas guru maupun siswa dalam pembelajaran fisika

4. Mengembangkan ketrampilan guru maupun siswa sehingga tercipta proses pembelajaran yang inovatif, efektif, tidak membosankan

5. Memberi kesempatan kepada siswa untuk mendiskusikan, mempresentasikan informasi yang diperoleh kepada pihak yang terkait.

6. Mengkondisikan siswa agar bisa berfikir lebih kreatif dan inovatif serta memiliki rasa tanggung jawab dalam mencari dan menyerap informasi

\section{METODE PENELITIAN Perencanaan Penelitian}

Tahap pertama adalah persiapan : sebelum pelaksanaan penelitian, peneliti sudah melakukan refleksi terhadap prestasi belajar yang diperoleh oleh para siswa melalui metoda dokumenter, kemudian mengidentifikasi permasalahan yang terjadi. Hasil rumusan masalah pada penelitian harus dijadikan landasan untuk melakukan suatu hipotesis tindakan kelas. Penelitian tindakan kelas ini dilaksanakan di SMA Negeri 1 Sumenep pada semester ganjil bulan 20 Juli 2013. Pada tahap persiapan penelitian, diawali dengan penentuan materi pembelajaran yang dituangkan kedalam sekenario pembelajaran kemudian memilih model pembelajaran, strategi pembelajaran CBSA (cara belajar siswa aktif), metoda 
keterampilan proses (eksperimen), dan metoda problem solving, lalu menentukan instrumen yang diperlukan selama penelitian berlangsung. Tahap kedua adalah pendekatan dan rancangan penelitian yang bertujuan untuk mengetahui prestasi belajar fisika siswa secara optimal, peneliti menggunakan pendekatan tipologi penyediaan input analitik sebagai berikut :

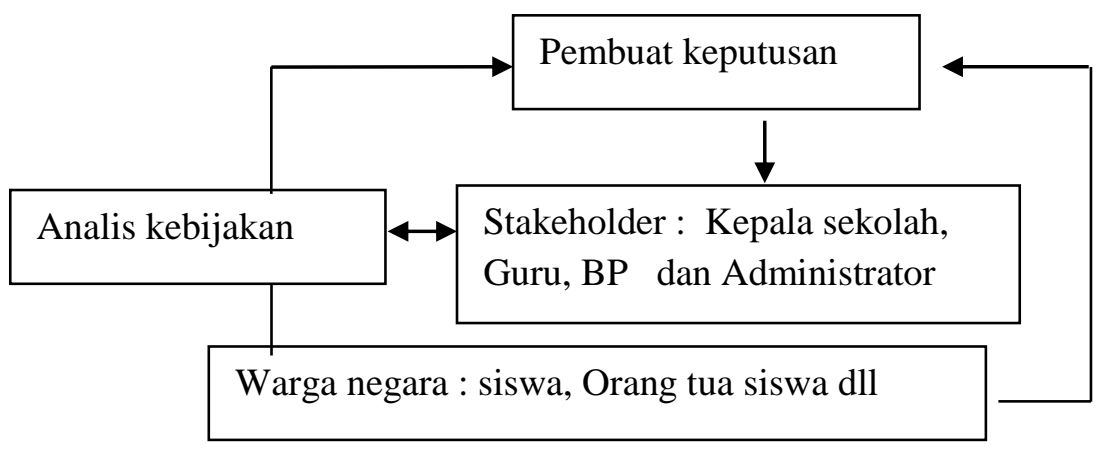

Gambar 1. Tipologi penyediaan Input Analitik

Analisis kebijakan adalah sekumpulan orang yang dianggap pakar dalam bidangnya, dalam penelitian ini analis kebijakan harus berperan untuk menstrukturkan dan memproses masukan masukan dari Stakeholder dan mentransformasikan kedalam penasehat kebijakan.

Stakeholder adalah orang yang dianggap mempunyai kewenangan dalam suatu birokrasi kelembagaan. Stakeholder terdiri dari Kepala sekolah Guru, Bimbingan Penyuluhan (BP) dan Administrator. Stakeholder berperan untuk memasok informasi dan opini pada forum yang di stukturkan oleh para analis, praktisi dan ahli lainnya.
Warga Negara, yang dimaksud warga negara disini adalah siswa, dan orang tua siswa yaitu semua orang yang terlibat secara langsung dalam penulisan karya ilmiah ini dan fungsinya berperan memasok informsi dan opini baik kepada analis maupun pembuat keputusan

Pembuat keputusan adalah seseorang yang sedang merencanakan dan melakukan sebuah penelitian.

Agar pelaksanaan penelitian bisa berjalan dengan lancar maka perlu dibuat diagram rancangan penelitian. Adapun diagram rancangan penelitian tindakan kelas dapat dilihat pada diagram sbb :

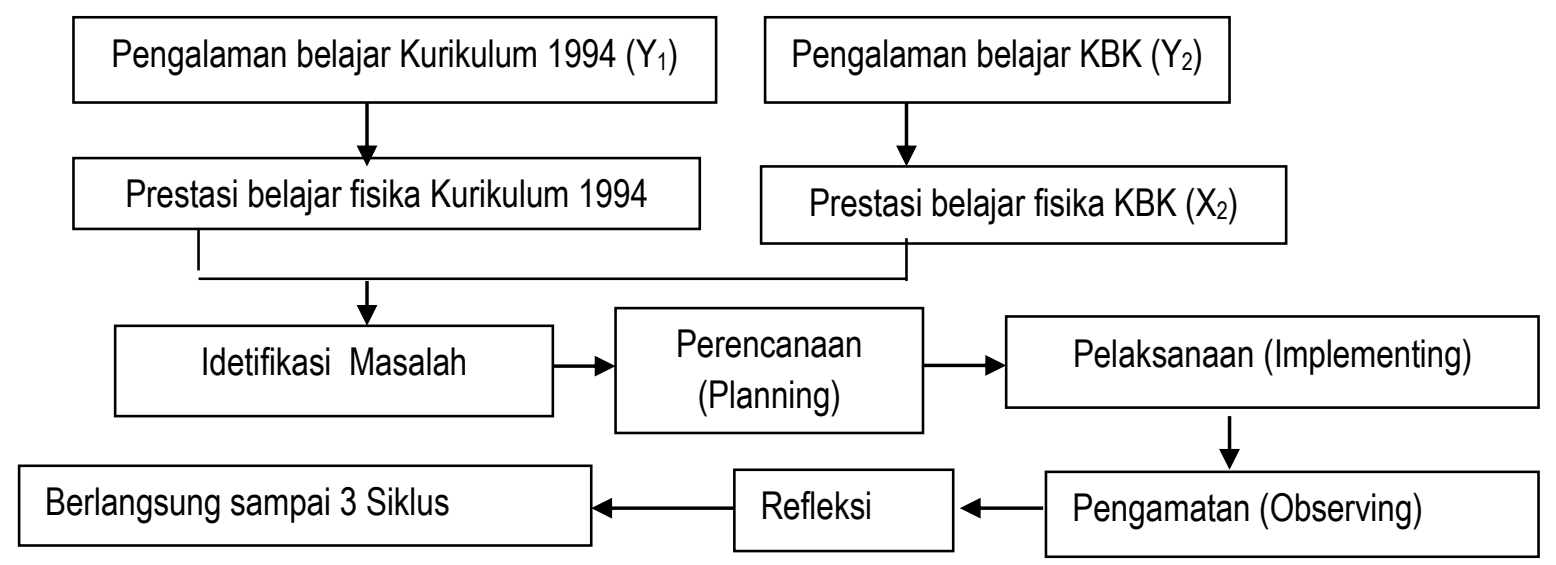

Gambar 2. Rancangan Penelitian 


\section{Prosedur Pelaksanaan Tindakan}

Tahap pertama : diskrepsi proses belajar mengajar pada siklus pertama, kedua dan ketiga guru menentukan pokok bahasan seperti pada tabel berikut :

Tabel 1. Materi Pokok Bahasan

\begin{tabular}{|c|c|c|c|c|}
\hline No & Materi Pokok & Waktu & Media/Sumber pembelajaran & Keterangan \\
\hline 1. & Posisi / Gerak Lurus & $3 \mathrm{jp}$ & $\begin{array}{l}\text { Buku paket } \\
\text { Media/Charta/alat Peraga }\end{array}$ & \multirow{3}{*}{$\begin{array}{l}\text { Pembelajaran } \\
\text { experimen di } \\
\text { Laboratorium } \\
\text { Fisika }\end{array}$} \\
\hline 2 & Hukum Newton tentang gerak & $3 \mathrm{jp}$ & $\begin{array}{l}\text { Buku paket } \\
\text { Media/Charat/alat Peraga/OHP }\end{array}$ & \\
\hline 3 & Gerak Melingkar & $3 \mathrm{jp}$ & $\begin{array}{l}\text { Buku paket } \\
\text { Media/Charat/alat } \\
\text { Peraga/OHP/VCD }\end{array}$ & \\
\hline
\end{tabular}

Tahap kedua : Melaksanakan diskrepsi proses belajar mengajar pada siklus pertama, kedua dan ketiga yaitu guru membuat skenario pembelajaran Fisika yang disyaratkan dalam PBI sebagai berikut :

$>$ Guru menjelaskan tujuan pembelajaran, kemudian menjelaskan logistik/sarana yang dibutuhkan oleh siswa pada saat pembelajaran berlangsung baik di dalam kelas maupun diluar kelas, memberikan motivasi kepada siswa agar mampu melaksanakan pembelajaran secara mandiri dengan sumber pembelajaran yaitu buku, lingkungan/latar dan internet serta para ahli fisika dan lain sebagainya

Membimbing siswa agar dapat memahami konsep atau pokok bahasan yang disajikan oleh guru, hal ini harus diikuti dengan kritis, aktif dan kreatif, kemudian mendifinisikan dan mengorganisasikan tugas belajar yang berhubungan dengan masalah yang sedang dipelajari oleh siswa (menetapkan topik, tugas, jadwal dll)

Guru mendorong siswa untuk mengumpulkan informasi yang sesuai, eksperimen untuk mendapatkan penjelasan dan pemecahan masalah, pengumpulan data, hepotesis, pemecahn masalah.

Guru berusaha bersifat ramah, sabar, komonikatif, perhatian serta membantu siswa yang mengalami kesuliatan dalam menyususun laporan eksperimen.

Melakukan kegiatan evaluasi pembelajaran untuk mengetahui hasil belajar kemudian merefleksi aktivitas pembelajaran

Model pembelajaran PBI ini bisa berjalan dengan efektif jika didukung oleh beberapa faktor diantaranya adalah sumber daya manusia (SDM) dan faktor penunjang lainnya seperti sarana prasarana yang memadai.

Tahap ketiga : Membuat skala penilaian dari hasil analisis data yang diperoleh selama penelitian berlangsung adalah sebagai berikut :

Tabel 2. Skala Penilaian

\begin{tabular}{|c|c|c|}
\multirow{2}{*}{$\begin{array}{c}\text { Observasi/Angket/inter- } \\
\text { view Prestasi belajar } \\
\text { dalam bentuk }\end{array}$} & \multirow{2}{*}{ Keterangan } \\
\cline { 1 - 2 } Angka & Huruf & \\
\hline 10 & A & Istimewa \\
\hline $8-9$ & $\mathrm{~B}$ & Baik sekali \\
\hline $6-7$ & $\mathrm{C}$ & Cukup baik \\
\hline $4-5$ & $\mathrm{D}$ & Kurang \\
\hline $1-4$ & $\mathrm{E}$ & Sangat kurang \\
\hline
\end{tabular}

\section{Pengamatan :}

Penggunakan model pembelajaran problem based introduction, menciptakan aktivitas dan kreatifitas, motivasi siswa muncul sehingga untuk belajar fisika semakin kelihatan dan siswa lebih mudah memahami konsep-konsep fisika yang disampaikan oleh guru. Dari paparan yang tersebut diatas peran guru diharapkan dapat : 
$>$ Meningkatkan pembelajaran dengan penekanan pada pemanfaatan sumber belajar yang optimal agar lebih menarik dan dapat perhatian atau dapat memotivasi belajar siswa.

> Aktif memantau kegiatan belajar siswa sehingga memgetahuii hambatan-hambatan yang dialami oleh siswa dalam memahami suatu konsep yang sedang dipelajari.

$>$ Membimbing siswa yang mengalami kesulitan dalam memahami suatu konsep atau menyelesaikan berbagai ragam tugas yang harus diselesaikan siswa

$>$ Membimbing siswa dalam mengexplorasi sumber belajar yang telah disiapkan oleh sekolah

\section{Refleksi}

Pada tahap Refleksi kegiatan penelitian selalu dilaksanakan setiap akhir siklus. Refleksi pada penelitian ini didasarkan atas penilaian kognetif, afektif dan psikomotorik siswa selama proses pembelajaran. Hasilnya dipakai sebagai bahan pertimbangan, apakah rencana pembelajaran berikutnya statis seperti pembelajaran semula atau pembelajaran dengan inovasi, modifikasi agar sampai pada taraf yang dianggap sempurna oleh guru pengajarnya. Semua hasil penelitian dijadikan bahan pertimbangan oleh peneliti sekaligus pengajar dikelas untuk menentukan bagian pembelajaran mana yang perlu mendapatkan perbaikan atau modifikasi. Hal ini dilakukan demi terlaksananya tindakan berikut yang lebih baik dan mantap.

\section{Subyek Penelitian}

Populasi atau sample penelitian ini adalah siswa kelas $\mathrm{X}^{-\mathrm{MIA}_{4}}$ SMA Negeri 1 Sumenep semester ganjil tahun pelajaran 2013/2014. Jumlah siswa 37 orang terdiri dari 24 perempuan dan 13 laki-laki mempunyai kemampuan intelektual yang hampir homogen

\section{Instrumen Penelitian}

Dalam melakukan penelitian ilmiah, seorang praktisi harus menguasai dasar atau landasan berfikir metodis untuk sistimatis penelitian. Berhasil dan tidaknya suatu penelitian, baik dan buruknya hasil suatu penelitian tergantung pada metode yang digunakan dalam pengumpulan data. Pengumpulan data pada penelitian ilmiah bertujuan memproleh hasil kesimpulan yang akurat, releable dan relevan, untuk memperoleh data yang dimaksudkan, penelitian dilaksanakan dengan menggunakan teknik, prosedur dan media yang dapat dipertanggung jawabkan. Penentuan metode bersifat memberikan arah dalam pelaksanaan penelitian (research). Pengambilan sampel diperoleh melalui cara stratfied purposive random sampling yaitu suatu metoda statistik untuk medapatkan sampel yang represintatif. Metoda yang digunakan adalah randomisasi, cara inilah yang paling banyak digunakan dalam penulisan karya ilmiah. Usaha untuk mengumpulkan data peneliti memerlukan metode utama atau metode pokok yaitu metode test dan metode pelengkap lainnya ialah ;

a. Metode test

Metode test merupakan metode pokok, usaha peneliti untuk memperoleh datadata tentang hasil belajar siswa, yaitu (pre test) memberikan pertanyaanpertanyaan secara lesan yang harus dijawab oleh siswa dan (post test pilihan ganda) soal-soal yang harus dikerjakan oleh siswa.

b. Metode observasi

Metode observasi adalah suatu cara penelitian untuk mengumpulkan data dengan jalan melalui pengindraan sehingga dengan demikian dapat dikatakan bahwa data yang diperoleh merupakan hasil dan pengindraan dan penglihatan (dilakukan pada saat pembelajaran berlangsung). Menurut Deobald V. Dalen ("observasi is fundamental in research for it produce oene of the basic element of sience facts. Observing is an activity the research worker changes in through out the several stages of his investigations..") oleh karena itu 
observasi dijalankan dengan menggunakan alat indra, segala sesuatunya dapat ditangkap dengan indra dan dapat di observasi. Karena observasi itu menyangkut masalah yang sangat kompleks, observasi harus bersifat sensitif dalam menangkap masalah. Observasi peneliti menggunakan participant observations (observasi yang berpartisipasi). Dalam observasi bentuk ini maka observer (pembimbing) turut mengambil bagian didalam situasi dari orang diobservasinya (observes)

c. Metode interview

Interview adalah salah satu metode untuk mendapatkan data dalam penelitian yang dilakukan secara langsung dengan informan (face to face relation), dilakukan setelah usai pembelajaran. Karena obyek penelitiannya hanya terbatas pada kelas X/MIA-4 maka peneliti menggunakan personal interview (dilaksanakan antara interview dan interviewer secara langsung dan perseorangan).

d. Metode dokumentasi

Metoda dokumentasi adalah suatu cara pencatatan dari segala hasil penelitian. Penulisan data hasil observasi dan interview sampai pada hasil eksperimen dan tes dicatat sebagai bahan analisa penelitian.

e. Metode angket

Metode angket adalah suatu cara untuk mengumpulkan dan memberikan data yang sebenarnya secara tertulis melalui beberapa pertanyaan kepada subyek atau obyek penelitian baik secara langsung maupun tidak langsung. Pada penelitian ini angket diberikan pada saat usai pembelajaran pada setiap siklus. Dalam penelitian ini peneliti menggunakan Angket tak langsung (adalah angket yang itemitemnya diajukan kepada seseorang, tetapi dari item-item tersebut digunakan untuk mengungkap data orang lain).

\section{$\underline{\text { Teknik Analisis Data Penelitian }}$}

Semua data penelitian yang diperoleh secara selektif, dianalisis menggunakan statistik deskriptif kualitatif yaitu analitis data dilakukan dengan menggunakan teknik-teknik statistic sesuai dengan masalah dan tujuan peneliti serta jenis data yang dianalisis (Furqon,1997:15). Suatu hal yang perlu ditekankan didalam penelitian ini adalah teknik statistic harus diperlukan sebagai alat bantu dalam memahami data penelitian, bukan sebagai pengganti kemampuan dan kearifan peneliti. Untuk mengetahui efektifitas suatu metoda dalam kegiatan penelitian maka diperlukan analisis data. Adapun tahapan-tahapan yang dilakukan dalam analisis data adalah sebagai berikut :

a. Tahap persiapan : penyelesaian data empiris pada instrumen kuisioner di pindahkan ke dalam bentuk matrik meliputi data responden dari variable (X) yaitu Model pembelajaran problem based introduction dan variabel (Y) Prestasi belajar siswa

b. Seleksi Data : Setelah semua data terkumpul, kemudian dilakukan seleksi data. Hal ini dimaksudkan untuk memeriksa kriteria data yang diprasyaratkan dalam penelitian

c. Pemberian Kode : Pemberian kode dimaksudkan untuk membedakan jenis data yang diperoleh melalui hasil observasi, angket, interview dan dokumentasi dari responden

d. Pentabulasian data : Setelah diadakan seleksi data dan pembobotan maka langkah selanjutnya adalah mentabulasikan data, yaitu mengubah data dari instrumen pengumpul data menjadi tabel data. Kegiatan ini dimulai dari memberikan kode, menjumlahkan skor sampai membentuk data penelitian.

e. Hasil akhir dari kegiatan ini adalah menghasilkan tabel data tentang model pembelajaran problem PBI dan table data tentang prestasi belajar 
fisika siswa. Tabel data tersebut dikemas menjadi data pembelajaran PBI, merupakan hasil observasi pada siswa dan guru, angket, wawancara dan hasil tes siswa.

\section{Cara Mengambil Kesimpulan}

Penelitian ini berdasarkan atas prinsip kolaboratif dan koperatif. Penelitian yang bertujuan untuk meningkatkan prestasi belajar siswa ini, melibatkan partisipasi dari semua pihak yang terkait terutama stakeholder disekolah yang sedang diteliti. Beberapa hal yang dapat dilakukan oleh pihak yang terkait antara lain :

a. Pada tahap perencanaan penulisan PTK, Kepala sekolah banyak memberikan saran, motivasi dan fasilitas sekolah, ligitimasi kepada guru sebagai peneliti hingga akhir penelitian. Pada tahap ini juga peran guru BP dan wali kelas banyak memberikan informasi tentang keberadaan (eksistensi) siswa yang sedang diteliti.

b. Kemudian guru mata pelajaran sejenis yang tergabung dalam wadah MGMPSMA fisika yang banyak memberikan masukan tentang materi pembelajaran sebagai pembanding penelitian. Sedangkan keberadaan siswa adalah berperan sebagai obyek maupun subyek penelitian.

c. Pada tahap pelaksanaan PTK peneliti sebagai guru pengajar harus berkolaborasi dengan siswa, hal ini diharapkan seakan akan siswa tidak merasa bahwa dikelasnya sedang diteliti. Siswa sebagai obyek dan subyek penelitian dikondisikan proaktif melakukan kegiatan proses pembelajaran yaitu koperatif dalam bertanya dan menjawab pertanyaan, merangkum konsep dan mempresentasikan hasil diskusi bahkan mampu mengerjakan soal tes dari guru pengajar. Observasi, tahap ini peran guru sebagai peneliti sangat dominant.

d. Pada tahap refleksi guru sebagai peneliti harus dapat memutuskan langkah pembelajaran selanjudnya, apakah pembelajaran yang dilaksanakan cukup representatif atau pembelajaran perlu dimodifikasi, verifikasi dan sabagainya.

\section{HASIL PENELITIAN DAN PEMBAHASAN \\ Hasil Penelitian}

Dari pelaksanaan pembalajaran PBI bidang studi fisika yang dilakukan dikelas X/MIA-4 SMA Negeri 1 Sumenep diperoleh hasil penelitian sbb:

1. Terdapat masalah yang berkaitan dengan implementasi kegiatan belajar mengajar yaitu kompetensi guru dalam hal kesesuaian isi kurikulum (silabus), membuat program pembelajaran dan pelaksanaan program serta evaluasinya.

2. Terdapat beberapa temuan dari penggunaan model pembelajaran PBI, diantaranya adalah : Terbatasnya waktu, dana, sarana prasarana yang tersedia; Interaksi antara guru dan siswa; sumber dan media pembelajaran, pemanfaatan potensi latar yang kurang optimal.

Secara umum perbandingan hasil evaluasi pembelajaran fisika sebelum mengunakan model pembelajaran PBI, dengan sesudah menggunakan model pembelajaran problem based introduction adalah peran guru sangat dominant. Hasil rekapan nilai prestasi belajar fisika siswa kelas $\mathrm{X}_{-M I A}$ SMA Negeri 1 Sumenep semester ganjil tahun pelajaran 2013/2014 sebagai berikut :

Tabel 3. Hasil Nilai Rata-rata Prestasi Belajar Fisika Siswa

\begin{tabular}{|l|l|l|l|}
\hline \multicolumn{2}{|c|}{$\begin{array}{c}\text { Sebelum Model PBI } \\
\text { Prestasi belajar rata-rata kelas }\end{array}$} & \multicolumn{2}{c|}{$\begin{array}{c}\text { Sesudah PBI } \\
\text { Prestasi belajar rata-rata kelas }\end{array}$} \\
\hline 1. Nilal tugas + harian & 62 & 1. Nilai tugas + harian & 68 \\
\hline 2. Cara menjawab pertanyaan guru di kelas & 65 & 2. Cara menjawab pertanyaan Guru di kelas & 70 \\
\hline
\end{tabular}




\begin{tabular}{|l|l|l|l|}
\hline \multicolumn{2}{|c|}{$\begin{array}{c}\text { Sebelum Model PBI } \\
\text { Prestasi belajar rata-rata kelas }\end{array}$} & \multicolumn{2}{c|}{$\begin{array}{c}\text { Sesudah PBI } \\
\text { Prestasi belajar rata-rata kelas }\end{array}$} \\
\hline 3. Cara menyusun laporan & 64 & 3. Cara menyusun laporan & 70 \\
\hline 4. Ketelitian & 68 & 4. Ketelitian & 71 \\
\hline 5. Ketekunan, keuletan & 65 & 5. Ketekunan, keuletan & 72 \\
\hline 6. Usaha & 66 & 6. Usaha & 75 \\
\hline \multicolumn{1}{|c|}{ Jumlah nilai rata-rata } & $\mathbf{6 5}$ & \multicolumn{1}{c|}{ Jumlah nilai rata-rata } & 71 \\
\hline
\end{tabular}

Dari tabel tersebut diatas maka model pembelajaran PBI dianggap lebih baik, efektif dan efisien. Perubahan dan perkembangan hasil prestasi belajar fisika siswa tersebut secara rinci dapat dilihat melalui kegiatan pembelajaran setiap siklus berlangsung

\section{Siklus Pertama}

\section{Perencanaan (planing)}

Pada siklus pertama guru menerapkan skenario pembelajaran (RPP) yang menarik perhatian bagi siswa dan selalu berusaha bersikap ramah, komunikatif, sabar dan perhatian terhadap siswa (ing ngarso sung tulodo)

\section{Pelaksanaan (implementasi)}

Dengan menggunakan media transparan (OHP) guru berusaha dapat mengoptimalkan kegiatan belajar mengajar. Pemberian motivasi belajar dengan menggali informasi melalui sumber belajar yaitu buku, gambar gambar fenomena alam, ilustrasi media praktikum yang dipandu oleh guru diharapkan siswa dapat memecahkan masalah secara individu maupun kelompok. Materi pembelajaran pada siklus pertama adalah sebagai berikut :

Tabel 4. Materi Pembelajaran Persamaan gerak

\begin{tabular}{|l|l|c|l|l|}
\hline No & \multicolumn{1}{|c|}{ Materi Pokok } & Waktu & Media/sumber & Keterangan \\
\hline 1. & Vektor Posisi titik & $3 \mathrm{jp}$ & $\begin{array}{l}\text { OHP, Charta dan } \\
\text { Media lab. Buku, } \\
\text { VCD dan latar }\end{array}$ & $\begin{array}{l}\text { Menarik } \\
\text { perhatian } \\
\text { siswa }\end{array}$ \\
\cline { 1 - 2 } 2 & Kecepatan diturunkan dari fungsi posisi & \multirow{2}{*}{$2 \mathrm{jp}$} & & \\
\cline { 1 - 2 } & Percepatan diturunkan dari fungsi kecepatan & Evaluasi & & \\
\hline 5 & Penilaian proses & & \\
\hline
\end{tabular}

Penerapan dari model pembelajaran problem based introduction ini dapat meningkatkan motivasi belajar siswa baik internal maupun ekternal. Target yang paling utama adalah siswa lebih mudah memahami konsep-konsep fisika melalui pembelajaran tersebut, sehingga diharapkan prestasi belajar siswa menjadi meningkat.

\section{Pengamatan ( observasi )}

Dari hasil pengamatan pada penelitian tentang kegiatan pembelajaran pada siklus pertama didapatkan data sebagai berikut.

Tabel 5. Hasil Analisis Data pada siklus I

\begin{tabular}{|c|c|c|c|c|c|c|c|}
\hline \multicolumn{6}{|c|}{ Nilai rata-rata data penelitian } & \multirow{3}{*}{$\begin{array}{c}\text { Dokumentasi Nilai } \\
\text { Prestasi belajar } \\
\text { Sebelum PTK }\end{array}$} & Keterangan \\
\hline \multirow{2}{*}{ 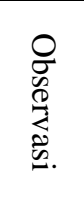 } & \multirow{2}{*}{ 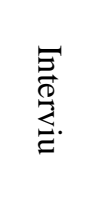 } & \multicolumn{2}{|c|}{ Angket } & \multirow{2}{*}{ 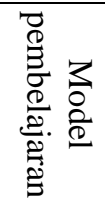 } & \multirow{2}{*}{ 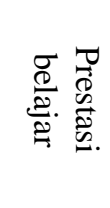 } & & \multirow[b]{2}{*}{$\begin{array}{c}\text { Terjadi peningkatan nilai } \\
\text { sebesar }\end{array}$} \\
\hline & & $\stackrel{g}{\Xi}$ & $\sum_{\infty}^{\infty}$ & & & & \\
\hline 7,80 & 8,20 & 7,70 & 8,50 & 8,05 & 7,10 & 6,50 & $60 \%$ \\
\hline
\end{tabular}




\section{Refleksi}

Dari hasil analisis terhadap data observasi, wawancara singkat, angket dan test digunakan sebagai bahan untuk menentukan penelitian tindakan selanjutnya. Setelah melakukan diskusi antar guru, kolaborator dan pembimbing, merefleksikan sebagai berikut:

a. Guru harus meningkatkan kualitas pembelajaran melalui penggunaan media dan teknik pembelajaran problem based introductuon. Penggunaan alat bantu media pembelajaran, secara optimal diharapkan dapat menarik dan meningkatkan perhatian atau motivasi belajar baik internal maupun eksternal pada siswa.

b. Penggunaan sumber belajar yang lebih variatif dengan menampilkan audio visual yang dapat merangsang keaktifan, kreatifitas dan gairah belajar siswa.

c. Guru harus memantau kegiatan belajar siswa sehingga mengetahui hambatanhambatan yang dialami siswa dalam memahami suatu konsep fisika secara utuh.

d. Memberikan pujian atau hadiah bagi siswa yang berhasil mamahami suatu konsep dan memberi semangat kepada siswa yang belum berhasil.

e. Membimbing siswa yang mengalami kesulitan-kesulitan dalam memahami suatu konsep atau menyelesaikan suatu soal dan memberi berbagai pengayaan bagi siswa yang tergolong pandai.

\section{Siklus Kedua Perencanaan (planing)}

Berdasarkan temuan berupa kelemahan atau kekurangan hasil refleksi siklus pertama ditindak lanjuti pada siklus yang kedua. Pada siklus kedua, guru disamping memberikan pembelajaran seperti pada siklus pertama juga memberikan penjelasan tentang cara penggunaan media/peralatan praktikum, cara menggali informasi melalui sumber pembelajaran yang relevan untuk memecahkan masalah yang dipelajari oleh siswa.

\section{Pelaksanaan (implementasi)}

Pada siklus kedua, siswa sudah secara langsung melakukan kegiatan praktikum secara kelompok, Proses Kegiatan belajar mengajar harus sesuai pada sekenario pembelajaran. Adapun materi pembelajaran terdapat pada tabel 6.

Tabel 6. Materi Pembelajaran Gerak Rotasi

\begin{tabular}{|c|c|c|c|c|}
\hline No & Materi Pokok & Waktu & Media/sumber & Keterangan \\
\hline 1 & Posisi Partikel & \multirow{5}{*}{3 jp } & \multirow{7}{*}{$\begin{array}{l}\text { OHP, Charta dan Media } \\
\text { laboratorium } \\
\text { Buku,VCD dan latar }\end{array}$} & \multirow{7}{*}{$\begin{array}{l}\text { Menarik } \\
\text { perhatian } \\
\text { siswa }\end{array}$} \\
\hline 2 & Kecepatan sudut & & & \\
\hline 3 & Percepatan sudut & & & \\
\hline 4 & Kinematika Rotasi & & & \\
\hline 5 & Dinamika Rotasi & & & \\
\hline & Evaluasi & \multirow[t]{2}{*}{$2 \mathrm{jp}$} & & \\
\hline & Penilaian proses & & & \\
\hline
\end{tabular}

Hasil praktikum dijadikan bahan diskusi kelompok kemudian hasilnya dikomfirmasikan pada buku rujukan/ literatur.

\section{Pengamatan (observasi)}

Dari hasil analisis penelitian tentang kegiatan pembelajaran pada siklus kedua didapatkan data sebagai berikut. 
Tabel 7. Hasil Analisis Data pada siklus II

\begin{tabular}{|c|c|c|c|c|c|c|c|c|}
\hline \multirow[t]{3}{*}{ No } & \multicolumn{6}{|c|}{ Nilai rata-rata data penelitian } & \multirow{3}{*}{$\begin{array}{l}\text { Dokumentasi Nilai } \\
\text { Prestasi belajar } \\
\text { Siklus I }\end{array}$} & Keterangan \\
\hline & \multirow{2}{*}{$\begin{array}{l}0 \\
0 \\
0 \\
0 \\
0 \\
0.2\end{array}$} & \multirow{2}{*}{ 蛋 } & \multicolumn{2}{|c|}{ Angket } & \multirow{2}{*}{ 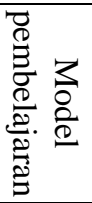 } & \multirow{2}{*}{ 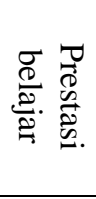 } & & \multirow{2}{*}{$\begin{array}{l}\text { Terjadi peningkatan } \\
\text { nilai sebesar }\end{array}$} \\
\hline & & & Guru & siswa & & & & \\
\hline 1 & 8,00 & 8,40 & 7,80 & 8,50 & 8,18 & 7,75 & 7,10 & 0,65 \\
\hline
\end{tabular}

\section{Refleksi}

Berdasarkan dari analisis, ternyata masih terdapat ganjalan yang harus diperbaiki contohnya adalah sebagai berikut :

1. Kualitas pembelajaran dengan penggunaan media pembelajaran dan sumber belajar untuk siswa masih dianggap kurang sempurna, hal ini dapat dilihat dari aktifitas siswa dalam pembelajaran. Belum semua siswa aktif melakukan prektikum dan menggali informasi melalui sumber pembelajaran.

2. Penggunaan media audio visual dianggap masih kurang variatif yaitu berupa tulisan, bagan, gambar dan grafik maupun gambar animasi tanpa kombinasi gambar hidup

3. Guru dianggap kurang memfasilitasi keberadaan sumber belajar yang dibutuhkan oleh siswa, kurang memotivasi dan menarik perhatian siswa agar lebih aktif dan kreatif dengan menggunakan kombinasi transparansi berupa rangkaian gambar-gambar yang menunjukkan suatu peristiwa fenomena alam.

4. Guru tidak memberikan bimbingan terhadap siswa dalam menyusun rangkuman suatu konsep.

5. Guru tidak memberikan bimbingan terhadap siswa yang mengalami kesulitan belajar baik secara umum maupun perseorangan.

Dari uraian atau paparan yang tersebut diatas maka tindakan guru selanjutnya adalah berusaha menyempurnakan proses pembelajaran pada siklus ketiga.

\section{$\underline{\text { Siklus Ketiga }}$}

\section{Perencanaan}

Perencanaan proses belajar mengajar pada siklus ketiga, merupakan tindak lanjut dari refleksi siklus kedua. Pada siklus ketiga ini guru melakukan strategi pembelajaran yang hampir sama dengan siklus pertama dan kedua. Pada siklus ketiga sifatnya hanya mennyempurnakan tindakan yang terjadi di siklus kedua. Oleh karena itu peningkatan kualitas pembelajaran dengan penekanan sebagai berikut :

a. Menggunakan media pembelajaran OHP/VCD yang bervariatif dengan kombinasi berupa tulisan, bagan, gambar, grafik maupun gambar animasi untuk memotivasi dan menarik perhatian siswa.

b. Membimbing siswa menyusun rangkuman atau resume suatu konsep yang diperoleh siswa melalui sumber pembelajaran

c. Memberikan pujian/hadiah kepada siswa yang berhasil memahami suatu konsep fisika dan tetap memberi semangat yang belum berhasil, sehingga motivasi belajar semua siswa tetap terjaga.

d. Membimbing siswa yang mengalami kesulitan belajar baik secara umum maupun perseorangan.

\section{Pelaksanaan (implementasi)}

Pada tindakan siklus ketiga ini siswa langsung menggali informasi dari beberapa sumber belajar, melakukan kegiatan diskusi/informasi kemudian melakukan kegiatan praktikum tentang Materi Pembelajaran Gerak Harmonik seperti tertera pada tabel dibawah ini : 
Tabel 8. Materi Pembelajaran Gerak Harmonik

\begin{tabular}{|c|c|c|c|c|}
\hline No & Materi Pokok & Waktu & Media/sumber & Keterangan \\
\hline 1. & Periode dan frekwensi & \multirow{5}{*}{$3 \mathrm{jp}$} & \multirow{6}{*}{$\begin{array}{l}\text { OHP, Charta dan } \\
\text { Media } \\
\text { laboratorium } \\
\text { Buku,VCD dan } \\
\text { latar }\end{array}$} & \multirow{6}{*}{$\begin{array}{c}\text { Menarik } \\
\text { perhatian } \\
\text { siswa }\end{array}$} \\
\hline 2 & Simpangan,Kecepatan dan percepatan GH & & & \\
\hline 3 & Grafik pada besaran GH & & & \\
\hline 4 & Fase,beda fase pada GH & & & \\
\hline 5 & Superposisi dan Energi & & & \\
\hline & Evaluasi & \multirow{2}{*}{ 2jp } & & \\
\hline & Penilaian proses & & & \\
\hline
\end{tabular}

Sedangkan proses kegiatan belajar mengajar harus mengacu pada sekenario pembelajaran yang telah disiapkan dan dilegalisasi oleh kepala sekolah

\section{Pengamatan (observasi)}

Dari hasil analisis penelitian tentang kegiatan pembelajaran ketiga didapatkan data sebagai berikut.

Tabel 9. Hasil Analisis Data pada siklus ketiga

\begin{tabular}{|c|c|c|c|c|c|c|c|c|}
\hline \multirow{3}{*}{$\begin{array}{l}\mathrm{N} \\
\mathrm{O}\end{array}$} & \multicolumn{6}{|c|}{ Nilai rata-rata data penelitian } & \multirow{3}{*}{$\begin{array}{c}\text { Dokumentasi Nilai } \\
\text { Prestasi belajar } \\
\text { Siklus II }\end{array}$} & Keterangan \\
\hline & \multirow{2}{*}{ 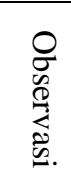 } & \multirow{2}{*}{ 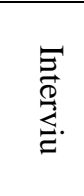 } & \multicolumn{2}{|c|}{ Angket } & \multirow{2}{*}{ 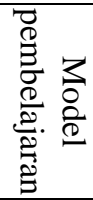 } & \multirow{2}{*}{ 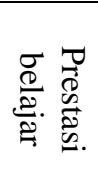 } & & \multirow{2}{*}{$\begin{array}{l}\text { Terjadi peningkatan } \\
\text { nilai sebesar }\end{array}$} \\
\hline & & & Guru & Siswa & & & & \\
\hline 1 & 8,20 & 8,50 & 7,90 & 8,60 & 8,45 & 7,65 & 7,75 & 0,70 \\
\hline
\end{tabular}

Diperoleh hasil bahwa pada siklus ketiga baik guru maupun siswa telah terbiasa dengan penggunaan media pembelajaran yaitu media transparan, Laboratarium dan VCD pembelajaran bahkan pada pemanfaatan sumber belajar. Dalam proses belajar mengajar yang disampaikan guru sudah cukup meyakinkan, semakin menarik dan lebih mudah dipahami oleh siswa. Pada siklus ketiga ini siswa sendiri telah dapat memanfaatkan semua media dan berdiskusi dengan guru maupun siswa lain, terutama konsep-konsep yang membutuhkan visualisasi data atau gambar suatu peristiwa maupun hasil pengamatan/eksperimen.

Suasana kegiatan belajar mengajar cukup kondusif, guru dapat membuka kesempatan seluas-luasnya bagi siswa untuk menyampaikan ide atau beberapa pertanyaan yang dibawa ke dalam diskusi kelas baik guru dengan siswa maupun antar siswa di kelas. Motivasi belajar siswa semakin tampak meningkat, ini dapat dilihat dari suasana pembelajaran yang semakin bergairah, semakin hidup ditandai dengan siswa semakin banyak yang aktif mengajukan pertanyaan maupun menanggapi suatu permasalahan.

\section{Faktor siswa}

Dari hasil pemantauan lembar observasi siswa (LOS) menunjukkan bahwa suasana kelas semakin hidup dan bergairah. Perhatian siswa terhadap guru yang sedang menyajikan konsep/materi menggunakan VCD, media Laboratorium dan lingkungan latar sebagai pembelajaran sangat antusias, interaksi antar guru dengan siswa maupun antar siswa cukup optimal dan asiwa akrab dengan guru. Sebagian besar siswa sudah berani menjawab pertanyaan maupun mengajukan pertanyaan dalam forum diskusi. Bahkan pada siklus ketiga ini siswa sudah dapat menyusun rangkuman materi pelajaran yang dipandu oleh guru. 


\section{Faktor guru}

Dari hasil pemantauan kolaborator melalui lembar observasi guru diperoleh hasil bahwa pembelajaran yang dilakukan oleh guru dengan media media Laboratorium dan VCD pembelajaran serta obyek lingkungan latar semakin mantap. Guru berperan sebagai mitra siswa dalam memahami suatu konsep fisika melalui diskusi maupun pengamatan/eksperimen. Guru telah cukup optimal memberi motivasi kepada siswa baik melalui wacana, pengalaman langsung, eksperimen maupun melalui gagasan keratif inovatif yang disajikan dengan VCD sehingga dapat memperluas pengetahuan dan wawasan siswa. Bimbingan guru dalam pembuatan rangkuman suatu konsep/materi berkurang karena sebagian besar siswa sudah dapat menyusun rangkuman sendiri.

\section{Refleksi}

Berdasarkan analisis hasil akhir test tentang konsep yang dibahas pada setiap siklus ternyata diperoleh nilai rata-rata kelas 7,10 (tujuh koma satu nol)-7,75 (tujuh koma tujuh lima) dan 8,45 (delapan koma empat lima). Maka terjadi peningkatan sebesar $60 \%$ - 0,65\% dan $70 \%$ dari proses pembelajaran yang dilaksanakan pada setiap siklus . Hasil nilai rata rata pada siklus ketiga ini menunjukan bahwa proses pembelajaran dianggap telah memenuhi nilai standar kegiatan belajar minimum yaitu 75 (tujuh puluh lima) yang diprasyaratkan oleh SMA negeri 1 Sumenep.

Oleh karena itu model pembelajaran problem based introduction dianggap mampu meningkatkan prestasi belajar fisika siswa dan harus direkomandasikan untuk dikembangkan dikelas atau pada sekolah yang lain.

\section{Pembahasan}

Sebagaimana diketahui, bahwa perkembangan kurikulum yang dilakukan oleh pemerintah dari waktu kewaktu senantiasa kurang memuaskan dalam hal menyelesaikan masalah kesesuaian antara apa yang diajarkan di sekolah dengan kebutuhan riil di masyarakat yaitu dalam bentuk isu "pembentukan siswa yang siap pakai dan bukan hanya siap tahu", kemudian "Perlunya link ant match antara pelajaran di sekolah dengan tuntutan masyarakat kerja" semuanya itu mengarah pada tercapainya kesesuaian antara kajian akademis terhadap masalah sosial di sekolah dengan tuntutan masyarakat pada lulusan lembaga sekolah itu sendiri (Hadi Nur, 2003: 15).

Oleh karena itu pengembangan kurikulum harus di selaraskan atau diikuti dengan strategi pembelajaran sampai pada pengembangan model pembelajarannya (Sa'dun Akbar, 2003). Penelitian ini menelaah salah satu di antara model pembelajaran yang dapat dikembangkan di sekolah adalah model pembelajaran problem based introductuon. Penggunaan model pembelajaran problem based introduction pada bidang studi fisika mempunyai tujuan yaitu menerapkan pengetahuan siswa dan mengembangkan kemampuan siswa dalam memecahkan masalah. dengan ketrampilan berfikir secara kritis (Ratna W, 1990). Model pembelajaran seperti ini sangat relevan untuk meningkatkan daya kreativitas siswa yang berhubungan dengan konsep-konsep fisis dan dinamika sosial yang timbul, jika diimbangi dengan penggunaan pendekatan dan metode pembelajaran yang sesuai dengan lingkungan (latar) yang kondusif dan sarana prasarana yang memadai serta eksistensi guru yang profesional (Jurnal Educational Leadership: 1993, dalam Supriadi: 1998) Untuk memperoleh hasil pembelajaran yang optimum, maka pola pembelajaran model problem based introduction dengan menggunakan strategi CBSA, pendekatan ketrampilan proses dan lingkungan (latar) serta penggunaan metode yang bervariasi yaitu 
problem solving, diskusi/informasi, eksperimen dan karya wisata merupakan sebuah alternatif pilihan. Model pembelajaran PBI pada setiap siklus setelah diuji cobakan, membutuhkan waktu $3 \times 45$ menit untuk semua jenis kompetensi dasar bidang studi fisika.

Pada awal pembelajaran guru memberikan apersepsi yaitu menunjukan beberapa media pembelajaran di kelas atau peralatan laboratarium sekolah atau suatu obyek di luar sekolah, kemudian guru memberikan penjelasan secara singkat tentang media, alat laboratorium atau suatu obyek, memberikan motivasi yang berhubungan dengan fenomena alam yaitu sebagai sumber pembelajaran.

Setelah itu guru mengajukan suatu pertanyaan yang harus dijawab oleh siswanya. Pertanyaan yang diberikan oleh guru tersebut adalah pertanyaan yang berhubungan dengan prasayarat ilmu pengetahuan yang harus dimiliki oleh siswa kemudian guru membantu siswa dalam mendifinisikan dan mengorganisasikan pokok bahasan atau kompetensi dasar yang akan di pelajarinya.

Jika siswa merespon dan saling berebut untuk menjawab pertanyaan, maka guru sebagai fasilitator harus segera mendistribusikan pertanyaan berikutnya melalui Lembar Keria Siswa (LKS) kepada seluruh siswa di kelas. LKS tersebut di dalamnya berisi sebuah problematika konsep fisis yang harus dipecahkan secara kolektif oleh siswa dalam suatu kelompok-kelompok kecil.

Problematika dari konsep fisis yang termuat di dalam LKS harus dipecahkan hanya melalui suatu media atau harus melakukan experimen atau meninjau keberadaan obyek di luar kelas. Pemecahan masalah dilakukan dalam rangka untuk mendapatkan beberapa konsep.Pada saat siswa melakukan pemecahan masalah aspek kerjasama, kekompakan, gotong royong dan kebersamaan serta kepedulian sangat dibutuhkan, oleh karena itu guru diharapkan mampu memberikan motivasi untuk dikembangkan, sehingga nilai-nilai kebudayaan tersebut secara tidak langsung telah tertanam pada jiwa setiap siswa (Koentjaraningrat, 1985: 25).

Beberapa konsep yang diperoleh oleh setiap kelompok, hasilnya perlu didiskusikan lagi antar kelompok (pleno), untuk menyamakan persepsi tentang konsep, maka guru memberikan intruksi agar setiap siswa membuka buku pelajaran sebagai referensinya. Di sinilah peran guru sebagai fasilitator dan moderator yaitu membantu siswa dalam mempresentasikan hasil diskusi kelompok dan memfasilitasi sarana diskusi dan sekaligus mengatur jalannya diskusi kelas (Soewondo, 1972 dalam Arifin 2000).

Hasil akhir dari pembelajaran adalah kesimpulan diskusi yaitu rangkuman dari hasil diskusi antar kelompok siswa yang sudah mendapat persetujuan dari guru sebagai muderatomya. Dari hasil kesimpulan tersebut siswa diberikan motivasi untuk melakukan refleksi atau evaluasi terhadap proses pembelajaran yang dilakukan.

Sesungguhnya model pembelajaran problem based introduction adalah sebuah model pembelajaran yang menggabungkan antara pendekatan dan strategi serta tujuan pembelajaran (Conny Semiawan, 1986). Pola pembelajaran dengan sistem pendekatan ini nampak bahwa siswa berusaha menjawab suatu masalah yang biasa diberikan oleh gurunya, peran siswa begitu sangat aktif, sehingga sistem sosial juga muncul yaitu hubungan yang interaktif dan komunikatif antara guru dengan siswa dan siswa dengan siswa, hal ini semakin nampak ketika guru memberikan pertanyaan kepada siswa dan saat siswa melakukan diskusi antar siswa dan antar kelompoknya.

Jawaban atau kesimpulan yang diberikan oleh setiap kelompok sangat beragam, sebelum proses pembelajaran berakhir guru perlu memberikan 
wawasan bahwa hasil pengamatan, hasil praktikum dan sebagainya tidak akan mencapai hasil yang optimal karena terbatasnya kemampuan alat dan terbatasnya kemampuan indra manusia dalam proses observasi apalagi proses pengukuran, oleh karena itu guru bisa memberikan komentar yang sifatnya riligius pada siswa, bahwa apa saja yang ada di dunia ini tidak ada yang mempunyai sifat ideal (sempurna), jika kita ingin menggali kebenaran konsep fisika, pertanyaan yang terakhir adalah "siapa yang mengatur dan siapa yang mengendalikan!."

Pada tindakan kelas yang dilakukan pada siklus pertama hasil belajar siswa masih dibawah standar ketuntasan minimum, kemudian oleh peneliti harus dicari apa penyebabnya dan perlu adanya tindak lanjut, sedangkan tindakan yang dilakukan pada siklus kedua harus mengacu pada permasalahan yang timbul pada siklus pertama, pada siklus kedua hasil belajarnya sudah diatas standar ketuntasan, namun masih banyak kendala yang muncul sehingga oleh peneliti dianggap kurang sempurna kemudian dicari apa penyebabnya dan masih perlu adanya tindakan siklus penelitian berikutnya. Pada siklus ketiga hasil belajar lebih baik dan dianggap sempurna oleh peneliti sehingga tidak perlu ada tindakan siklus berikutnya. Hasil akhir dari pembelajaran yang dilakukan pada setiap siklus siswa harus menyadarinya bahwa tujuan akhir pembelajaran fisika yaitu meningkatkan keimanan dan ketaqwaan terhadap Tuhan Yang Maha Esa (Depdikbud, 1984). Hal ini dapat dilihat dari relevansi antara hasil belajar dan prilaku sikap siswa terhadap fenomena alam yang muncul setiap hari.

\section{PENUTUP}

\section{Kesimpulan}

Bertitik tolak dari latar belakang masalah, tujuan penelitian, hasil dan pembahasan penelitian yang telah dipaparkan di atas terdapat beberapa hal yang harus digaris bawahi diantaranya adalah sebagai berikut :

$>$ Pengamatan tentang aktivitas guru dan siswa berlangsung dengan baik. Ini ditandai dengan hidupnya tanya jawab yang terjadi di dalam kelas selama pembelajaran berlangsung, siswa merespon terhadap kegiatan berkelompok dan kebersamaan antara kelompok sangat baik, demikian juga dengan guru, semuanya berjalan dengan baik.

$>$ Hasil yang dicapai siswa dalam pembelajaran cukup baik, Hal ini ditandai dengan hasil kerja kelompok yang baik, dengan adanya variasi bahan ajar yang telah diciptakan siswa dalam kelompoknya. Setelah diberikan angket, siswa banyak yang berminat dalam pembelajaran yang menggunakan pembelajaran PBI.

Dari seluruh uraian dapat diambil suatu kesimpulan bahwa: Model pembelajaran problem based introduction dapat meningkatkan prestasi belajar fisika siswa ( pada pokok bahasan tentang gerak) di kelas ${\mathrm{X}-M I A_{4}}_{4}$ SMA Negeri 1 Sumenep tahun ajaran 2013/2014

\section{Saran}

Agar dapat menghasilkan prestasi belajar siswa yang lebih optimal, penggunaan model pembelajaran problem based introduction pada bidang studi fisika di sekolah maka:

1. Pola pembelajaran dengan model problem based introduction disarankan menggunakan pendekatan ketrampilan proses dan lingkungan serta metode yang dianjurkan oleh kurikulum yaitu problem solving, diskusi/informasi, eksperimen dan karya wisata.

2. Kemampuan guru dalam pengembangan model pembelajaran fisika melalui penelitian tindakan kelas (action research) masih sangat terbatas, terutama terbatasnya kemampuan guru dalam hal penggunaan sumber belajar dan 
media pembelajaran di samping itu dana dan tersedianya waktu untuk melakukan penelitian, oleh karena itu perlu perbaikan kinerja guru yaitu proses pengembangan pembelajaran melalui penelitian tindakan kelas (PTK). Kemudian produk PTK tersebut digunakan sebagai alat penilaian kinerja guru.

3. Implementasi kurikulum berbasis kompetensi bidang studi fisika perlu diikuti dengan pengurangan beban tugas yang bersifat administratif agar mereka bisa lebih terfokus pada pengembangan dan peningkatan praktek pendidikan disekolah yang dilakukannya melalui proses pembelajaran.

4. Menghimbau pada praktisi pendidikan agar kesadaran terhadap penggunaan potensi latar sebagai media dan sumber pembelajaran dan nara sumber pembelajaran perlu ditingkatkan, di samping itu dana, trasportasi, waktu dan keamanan siswa perlu dipertimbangkan.

\section{DAFTAR PUSTAKA}

Nur Hadi. 2003. Pengembangan Kurikulum. Malang: Universitas Kanjuruhan.

Ratna W. 1998. Peran Ketrampilan Proses dalam Pendidikan IPA. Bandung: IKIP.

Suharsimi A. 2000. Manajemen Penelitian. Jakarta: PT. Rineka Cipta.

Sa'dun Akbar, dkk. 2003. Kajian Kurikulum dan Model Pembelajaran. Malang: Litbang UM.

Koencaraningrat. 1985. Kebudayaan Mentalitas Dan Pembangunan. Jakarta: PT. Gramedia.

Yohanes S. 2000. Fisika itu Mudah. Jakarta: PT.Bina Sumber Daya MIPA.
Indrawati. 1998. Apa, Mengapa, dan Bagaimana Pendekatan STS, makalah pada pelatihan Pendidikan Lingkungan Hidup.

Katu, Nggandi. 1999. Belajar sebagai kegiatan aktif Setiap individu dalam mengkonstruksi Pengetahuan, makalah disajikan dalam Seminar/Lokakarya Pengembangan Cara Pembelajaran IPA di PPPG IPA Bandung, Tanggal 17-18 Juni 1999.

Tobing, Rangke L, Setia Adi, Hinduan. 1990. Model-Model Mengajar Metodik Khusus Pendidikan Ilmu Pengetahuan Alam Sekolah Dasar, makalah dalam penataran calon Penatar Dosen Pendidikan Guru SD (Program D-II).

Wilkins, Robert A. 1990. Model Lesson Bridging the gap between model of teaching and classromm application. Curtin University of Technology.

Depdikbud. 1977. Pembinaan dan Pengembangan Kurikulum. Jakarta: Ditpend Guru dan Tenaga Teknis.

Depdikbud. 1994. Petunjuk Pelaksanaan Proses Belajar Mengajar. Jakarta: Ditjen Dikdasmen.

Nurhadi, Agus GS. 2003. Pembelajaran Kontektual dan Penerapannya dalam KBK. Malang : Universitas Negeri Malang 
Jurnal Lentera Sains (Lensa)

50 Jurnal Lensa, Volume 5 Jilid I Mei 2015 